\title{
Analysis of Metal Content of Organic Foods
}

\author{
Suneeta Chandorkar ${ }^{1}$ and Nishigandha Vaze ${ }^{2}$ \\ ${ }^{I}$ (Asst. Prof. Department of Foods and Nutrition, The Maharaja Sayajirao University of Baroda, Vadodara, \\ India) \\ ${ }_{2}^{2}$ (Post Graduate Student Department of Foods and Nutrition, The Maharaja Sayajirao University of Baroda \\ Vadodara, India)
}

\begin{abstract}
Metal contamination of foods is emerging as a major health hazard to the consumers. Ingestion is the major route for the entry of toxic metals into human body. Research has been done on the metal contamination of conventionally grown raw as well as cooked foods hence the present study aimed to determine the metal content of organically grown foods as organic foods claim to have least artificial inputs. Organic food samples collected from organic food outlets of Vadodara city, prepared by market basket method were digested using wet digestion method. A total of (20 raw, 35 pre treated and 38 cooked food samples were analysed for $\mathrm{Al}, \mathrm{Cd}$, $\mathrm{Ni}, \mathrm{Pb}, \mathrm{Zn}, \mathrm{Cu}, \mathrm{Cr}, \mathrm{Fe}$, Se using AAS. Pre treatments resulted in considerable reduction in almost all the metals except $\mathrm{Al}$ and $\mathrm{Fe}$. The results of metal content of raw foods showed that $\mathrm{Cu}, \mathrm{Fe}, \mathrm{Zn}$, Ni and $\mathrm{Pb}$ were below the safe limits given by FAO WHO 2001 while Cd exceeded the safe limit of $0.2 \mu \mathrm{g} / \mathrm{g}$. Health risk was associated with the consumption of $\mathrm{Cd}$ and Ni from the intake of cooked organic foods analyzed as they exceeded the safe intake limits given by JECFA.
\end{abstract}

Key Words-Organic foods, toxic metals, AAS, pre treatments, health risk assessment

\section{Introduction}

Metal toxicity is emerging as a major health hazard for humans. [1]. Toxic metals gain entry into human body via three routes namely through ingestion, inhalation and dermal contact, of which ingestion through food and water is the major route Rapid industrialization coupled with waste disposal malpractices, changing agricultural practices, household and vehicular smoke has resulted into contamination of air, soil, surface and ground water. [2], [3], [4]. These in turn contaminate food crops and drinking water. Soil gets contaminated due to modern agricultural practices (like use of chemical fertilizers, pesticides and manures), atmospheric depositions and direct application of wastewater for irrigation. Use of chemical fertilizers results into elevated levels of $\mathrm{Cd}$ in the soil. [2]. $\mathrm{Ni}, \mathrm{Pb}, \mathrm{Cd}$ and $\mathrm{Cu}$ are the most commonly found toxic metals in the topsoil primarily introduced through waste water application for irrigation. [5], [6], [7]. When these crops are consumed as foods by humans, the metals enter human body and exert influence at cellular, tissue and systemic level, [1]. Hence, the farmers are adopting the organic farming practices to maintain the quality of soil and foods grown on it. [8]. Organic food refers to produce that has been grown without the use of artificial fertilizers, pesticides and other chemicals or genetically modified organism. A comparative study to determine the heavy metal content of conventionally grown versus organically grown vegetables showed that the organically grown vegetables exceeded the permissible limits given by WHO/FAO for $\mathrm{Pb}$ and $\mathrm{Cd}$. [9]. Studies conducted on conventionally grown foods have shown that health risk is associated with consumption of foods contaminated with Nickel, Cadmium, Arsenic, Zinc and Aluminium. [10], [11], [12].Therefore, the present study aimed at analysing the metal content of organically grown foods by market basket method. The health risk in study population was assessed using commonly used indices namely PTDI, PTWI, PTMI, TDI, THQ, HRI, ADI, DIM. [13].

\section{Methods and Materials-}

2.1 Sampling method- Hundred female subjects between the ages of 20 to 40 years were selected from free living population of urban Vadodara by snow ball technique and detailed dietary information regarding the consumption of various foods was taken by 7 days food diary and food frequency questionnaire. The raw foods mentioned by the study population in the food diary were purchased in organic form, from Organic food outlets in Vadodara city by market basket method. The food samples were purchased under the following food categories of cereals, pulses, whole legumes, roots and tubers, other vegetables, leafy vegetables, fruits and jaggery. The 20 food samples selected for the study were whole wheat flour (Triticum aestivum), rice (Oryza sativa), rice flakes (Oryza sativa), split red gram (Cajanus cajan), split green gram (Phaseolus aureus Roxb.), split black gram (Phaseolus mungo Roxb.), split bengal gram (Cicer arietinum), whole green gram (Phaseolus aureus Roxb.), kidney beans (Phaseolus vulgaris), whole bengal gram (Cicer arietinum), potato (Solanum tuberosum), tomato (Lycopersicon esculentum), cauliflower (Brassica oleacea, var, botrytis), egg plant 
(Solanum melongena) cabbage (Brassica oleracea), spinach (Spinacia oleracea), fenugreek leaves (Trigonella foenum graecum), sapota (Achras sapota), guava (Psidium cattleyanum) and jaggery (Saccharum offinarum).

2.2 Preparation of the samples- Raw foods were subjected to pre treatments namely washing the foods by tap water and soaking the foods for 15 minutes followed by washing. The foods were then cooked in the laboratory by standard household procedures and were digested by wet digestion method. The digested food samples were filtered, coded and immediately transferred to acid washed polyethylene bottles of food grade and stored in dark and cool place till further analysis. [14]

2.3 Detection of metals- The metal content of raw pre treated and cooked organic foods was analyzed using atomic absorption spectrophotometer LabIndia model AA7000. Aluminium, Cadmium, Nickel, Lead, Chromium, Zinc, Iron, Copper and Selenium were. Selenium was below detectable limits in all the foods.

2.4 Health risk assessment Based on the dietary information data collected from the study population, health risk assessment was done using indices as PTDI, PTWI, PTMI, PMTDI, TDI, UL given by JECFA.

\section{Results and discussion-}

3.1 Metal content of raw organic foods- Table 3.1 gives the metal content of various raw organic foods analyzed in the present study. Among all raw organic foods analyzed, Aluminium content was found to be highest in spinach $(11.15 \mu \mathrm{g} / \mathrm{g})$, followed by potato $(3.07 \mu \mathrm{g} / \mathrm{g})$ and kidney beans $(3.85 \mu \mathrm{g} / \mathrm{g})$.

Table 3.1 Metal content of raw organic foods $(\mu \mathrm{g} / \mathrm{g})$

\begin{tabular}{|l|l|l|l|l|l|l|l|l|}
\hline Foodstuff & $\mathbf{A l}$ & $\mathbf{C d}$ & $\mathbf{N i}$ & $\mathbf{P b}$ & $\mathbf{C r}$ & $\mathbf{Z n}$ & $\mathbf{F e}$ & $\mathbf{C u}$ \\
\hline Cereals* & $\mathbf{1 . 1 1}$ & $\mathbf{0 . 6 5}$ & $\mathbf{1 . 4 4}$ & $\mathbf{0 . 1 6}$ & $\mathbf{1 . 5 5}$ & $\mathbf{1 2 . 0 0}$ & $\mathbf{8 . 6 3}$ & $\mathbf{0 . 6 3}$ \\
\hline Wheat flour & 2.03 & 0.76 & 1.28 & 0.12 & 1.79 & 19.87 & 11.01 & 0.71 \\
\hline Rice & Nil & 0.52 & 0.91 & 0.10 & 1.36 & 11.25 & 3.98 & 0.37 \\
\hline Rice flakes & 1.29 & 0.67 & 2.13 & 0.26 & 1.5 & 4.88 & 10.89 & 0.81 \\
\hline Pulses* & $\mathbf{1 . 0 3}$ & $\mathbf{0 . 6 9}$ & $\mathbf{1 . 6 5}$ & $\mathbf{0 . 1 5}$ & $\mathbf{1 . 5 2}$ & $\mathbf{1 1 . 0 0}$ & $\mathbf{8 . 2 5}$ & $\mathbf{1 . 4 0}$ \\
\hline Split red gram & 0.45 & 0.44 & 2.16 & 0.25 & 1.40 & 4.48 & 8.28 & 0.95 \\
\hline Split green gram & 2.27 & 0.83 & 1.51 & 0.13 & 1.06 & 21.16 & 8.27 & 0.19 \\
\hline Split black gram & 0.31 & 0.77 & 2.03 & 0.14 & 1.61 & 19.75 & 7.41 & 0.88 \\
\hline Split bengal gram & 0.76 & 0.64 & 1.21 & 0.13 & 2.00 & 4.92 & 8.85 & 3.12 \\
\hline Bengal gram roasted & 1.37 & 0.75 & 1.33 & 0.12 & 1.52 & 4.66 & 8.44 & 0.85 \\
\hline Whole legumes* & $\mathbf{1 . 9 9}$ & $\mathbf{0 . 5 7}$ & $\mathbf{2 . 1 2}$ & $\mathbf{0 . 1 9}$ & $\mathbf{1 . 4 3}$ & $\mathbf{9 . 8 0}$ & $\mathbf{1 3 . 6 4}$ & $\mathbf{1 . 0 2}$ \\
\hline Whole green gram & 0.12 & 0.32 & 2.06 & 0.24 & 1.42 & 2.53 & 7.32 & 0.94 \\
\hline Kidney beans & 3.85 & 0.82 & 2.17 & 0.14 & 1.46 & 17.06 & 19.96 & 1.11 \\
\hline Roots and tubers* & $\mathbf{3 . 0 7}$ & $\mathbf{0 . 7 5}$ & $\mathbf{1 . 1 2}$ & $\mathbf{0 . 1 1}$ & $\mathbf{1 . 3 6}$ & $\mathbf{1 . 9 3}$ & $\mathbf{4 . 7 3}$ & $\mathbf{1 . 0 2}$ \\
\hline Potato & 3.07 & 0.75 & 1.12 & 0.11 & 1.36 & 1.93 & 4.73 & 1.02 \\
\hline Vegetables* & $\mathbf{1 . 2 8}$ & $\mathbf{0 . 6 4}$ & $\mathbf{1 . 6 5}$ & $\mathbf{0 . 1 7}$ & $\mathbf{1 . 5 1}$ & $\mathbf{3 . 7 2}$ & $\mathbf{4 . 2 9}$ & $\mathbf{0 . 4 2}$ \\
\hline Cauliflower & 2.15 & 0.69 & 1.33 & 0.13 & 1.29 & 6.65 & 1.75 & 0.31 \\
\hline Tomato & 1.55 & 0.77 & 1.16 & 0.13 & 1.59 & 1.89 & 6.79 & 0.37 \\
\hline Egg plant & 0.12 & 0.46 & 2.04 & 0.25 & 1.66 & 2.45 & 4.33 & 0.58 \\
\hline Leafy vegetables* & $\mathbf{4 . 2 5}$ & $\mathbf{0 . 5 9}$ & $\mathbf{1 . 7 0}$ & $\mathbf{0 . 2 2}$ & $\mathbf{1 . 5 8}$ & $\mathbf{2 . 3 9}$ & $\mathbf{9 . 8 8}$ & $\mathbf{0 . 4 1}$ \\
\hline Fenugreek leaves & 0.68 & 0.51 & 2.18 & 0.26 & 1.50 & 1.96 & 11.65 & 0.40 \\
\hline Spinach & 11.13 & 0.74 & 1.20 & 0.13 & 1.67 & 2.82 & 9.82 & 0.52 \\
\hline Cabbage & 0.94 & 0.51 & 2.08 & 0.27 & 1.57 & 2.06 & 8.18 & 0.31 \\
\hline Fruits* & $\mathbf{0 . 6 5}$ & $\mathbf{0 . 5 5}$ & $\mathbf{1 . 5 6}$ & $\mathbf{0 . 1 9}$ & $\mathbf{1 . 6 0}$ & $\mathbf{2 . 3 3}$ & $\mathbf{5 . 4 4}$ & $\mathbf{0 . 9 9}$ \\
\hline Guava & 1.65 & 0.70 & 1.02 & 0.13 & 1.73 & 2.07 & 2.69 & 0.86 \\
\hline Sapota & 0.14 & 0.44 & 2.10 & 0.25 & 1.49 & 2.59 & 8.19 & 1.12 \\
\hline Jaggery & $\mathbf{0 . 3 3}$ & $\mathbf{0 . 5 1}$ & $\mathbf{2 . 1 6}$ & $\mathbf{0 . 2 7}$ & $\mathbf{1 . 5 7}$ & $\mathbf{2 . 1 1}$ & $\mathbf{8 . 2 4}$ & $\mathbf{0 . 4 1}$ \\
\hline
\end{tabular}

*- mean values

Cadmium contamination was highest in green gram whole $(0.88 \mu \mathrm{g} / \mathrm{g})$ followed by tomato $(0.77 \mu \mathrm{g} / \mathrm{g})$, split black gram $(0.77 \mu \mathrm{g} / \mathrm{g})$, wheat flour $(0.76 \mu \mathrm{g} / \mathrm{g})$, bengal gram flour $(0.75)$, potato $(0.75 \mu \mathrm{g} / \mathrm{g})$ and spinach $(0.74 \mu \mathrm{g} / \mathrm{g})$. Dotse (2010) reported the cadmium content in spinach, cabbage to be $0.00 \mu \mathrm{g} / \mathrm{g}$ and that in tomato to be 0.05 $\mu \mathrm{g} / \mathrm{g}$. [9]. All the foods exceeded the safe limits of $0.2 \mu \mathrm{g} / \mathrm{g}$ for Cadmium given by FAO, WHO 2001. [15]. A 
study conducted in Vadodara has reported Cadmium contamination in conventionally grown raw rice and wheat to be $1.66 \mu \mathrm{g} / \mathrm{g}$ and $1.63 \mu \mathrm{g} / \mathrm{g}$ respectively which were much higher as compared to the findings of the current study. [16]. A study conducted in Karnataka has reported the concentration of Cadmium in conventional spinach to be as high as $1.50 \mu \mathrm{g} / \mathrm{g}$. [17]. A study carried out in Iran too has reported the highest concentration of Cadmium in conventional spinach $(2.54 \mu \mathrm{g} / \mathrm{g})$ and cabbage $(2.35 \mu \mathrm{g} / \mathrm{g})$. [18].

All the foods were far below the safe limits of $67 \mu \mathrm{g} / \mathrm{g}$ for Nickel given by FAO, WHO in 2001[14]. Dotse (2010) reported much higher values of Zinc in organically grown foods as compared to the values obtained in the present study. [9]. Orisakwe et al (2012) reported Nickel content in conventional wheat to be $0.39 \mathrm{mg} / \mathrm{kg}$. [19].

Concentration of Lead was found to be highest in jiggery followed by cabbage, fenugreek leaves, egg plant, green gram whole, rice flakes and split red gram $(0.27$ to $0.25 \mu \mathrm{g} / \mathrm{g})$. All the foods were within the safe limits of $0.3 \mu \mathrm{g} / \mathrm{g}$ for Lead given by FAO, WHO in 2001. [15]. A study conducted in Bangladesh has reported higher concentration of Lead in conventionally grown pumpkin $(4.76 \mu \mathrm{g} / \mathrm{g})$. [20].

Chromium was found to be in the range of $1.06-2.00 \mu \mathrm{g} / \mathrm{g}$ in all the raw organic foods analyzed in the present study. A study carried out in Karnataka has reported concentration of chromium in conventional spinach as $28.59 \mu \mathrm{g} / \mathrm{g}$ which is far higher than the results found in present study $(1.67 \mu \mathrm{g} / \mathrm{g})$. [17].

In the present study, the highest concentration of Zinc was recorded in split green gram $(21.16 \mu \mathrm{g} / \mathrm{g})$, followed by wheat flour $(19.87 \mu \mathrm{g} / \mathrm{g})$, kidney beans $(17.06 \mu \mathrm{g} / \mathrm{g})$, and rice $(11.25 \mu \mathrm{g} / \mathrm{g})$. All the foods were within the safe limits of $100 \mu \mathrm{g} / \mathrm{g}$ for Zinc given by FAO, WHO in 2001 [15]. Dotse (2010) reported much higher values of Zinc in organically grown spinach $(33.4 \mu \mathrm{g} / \mathrm{g})$, cabbage $(23.7 \mu \mathrm{g} / \mathrm{g})$ and tomato $(27.5 \mu \mathrm{g} / \mathrm{g})$ as compared to the results obtained in the present study $(2.82 \mu \mathrm{g} / \mathrm{g}, 2.06 \mu \mathrm{g} / \mathrm{g}$ and $1.89 \mu \mathrm{g} / \mathrm{g}$ respectively). [9] A study done in Karnataka, India reported the concentration of Zinc in conventionally grown spinach to be $61.42 \mu \mathrm{g} / \mathrm{g}$ which is higher than the results obtained in present study $(2.28 \mu \mathrm{g} / \mathrm{g})$. [17].

Iron content in raw organic foods was recorded highest in kidney beans $(19.96 \mu \mathrm{g} / \mathrm{g})$, followed by fenugreek leaves $(11.65 \mu \mathrm{g} / \mathrm{g})$, wheat flour $(11.01 \mu \mathrm{g} / \mathrm{g})$, rice flakes $(10.89 \mu \mathrm{g} / \mathrm{g})$ and jaggery $(8.24 \mu \mathrm{g} / \mathrm{g})$. All the foods were within the safe limits of $425 \mu \mathrm{g} / \mathrm{g}$ for Nickel given by FAO, WHO in 2001 [15].

In the present study concentration of Copper was found to be highest in split bengal gram $(3.12 \mu \mathrm{g} / \mathrm{g})$, followed by kidney beans $(1.11 \mu \mathrm{g} / \mathrm{g})$ and potato $(1.02 \mu \mathrm{g} / \mathrm{g})$. All the foods were below the safe limits of $40 \mu \mathrm{g} / \mathrm{g}$ for Copper given by FAO, WHO in 2001 [15]. The various conventional spinach sample collected from different location in Karnataka had a mean copper content of $>34 \mu \mathrm{g} / \mathrm{g}$ which exceeded the Indian safe limits of $30 \mu \mathrm{g} / \mathrm{g}$ for copper. [17].

\subsection{Effect of pre treatments on metal content of raw organic foods}

Most foods are subjected to pre treatments such as washing and/or soaking and washing prior to cooking. These treatments were employed to the foods under study and the resultant change in the metal content was studied. The results are presented in table $3.2 \mathrm{a}$ and $3.2 \mathrm{~b}$. It was observed that washing with tap water reduced the zinc content in kidney beans and sapota but an increase was observed in green gram whole, guava and spinach. On the other hand when washed with tap water, Lead content reduced in guava and split black gram. A remarkable increase was observed in Cadmium content of egg plant and rice. In absence of similar studies it is difficult to corroborate the above findings. Soliman (2001) and Arab in 2001 concluded that using acetic acid or sodium chloride solution was more efficient in reducing the content of the contaminants than just the tap water. [21], [22]. A study conducted in Egypt on effect of washing treatments on metal content of meat (in the form of bovine liver, muscle, kidney) has reported that, washing the meat with only tap water was less effective in reducing the content of $\mathrm{Pb}, \mathrm{Cd}, \mathrm{Mn}, \mathrm{Cu}, \mathrm{Zn}, \mathrm{Fe}$ from the meat, when compared to washing with acidic or basic reagent. Washing only by tap water resulted in decrease by $24.7 \%$ in Lead, $25.8 \%$ cadmium, 19.4\% of Zinc in bovine muscle, $15.2 \%$ in Lead, $15.1 \%$ in Cadmium, $8.3 \%$ in Zinc in bovine liver and $9.2 \%$ for Lead, $8.2 \%$ for Cadmium and $7.2 \%$ for Zinc in bovine kidney.[22]. 
Table 3.2 at Effect of pre treatments on the metal content of raw organic foods $(\mu \mathrm{g} / \mathrm{g})$

\begin{tabular}{|c|c|c|c|c|c|c|c|c|}
\hline Food & \multicolumn{2}{|l|}{$\mathrm{Ni}$} & \multicolumn{2}{|l|}{$\mathrm{Zn}$} & \multicolumn{2}{|l|}{$\mathrm{Pb}$} & \multicolumn{2}{|l|}{$\mathrm{Fe}$} \\
\hline & $\begin{array}{l}\text { Washin } \\
\mathrm{g}\end{array}$ & $\begin{array}{l}\text { Soaking } \\
\text { washing }\end{array}$ & $\begin{array}{l}\text { Washin } \\
\mathrm{g}\end{array}$ & $\begin{array}{l}\text { Soaking } \\
\text { washing }\end{array}$ & $\begin{array}{l}\text { Washin } \\
\mathrm{g}\end{array}$ & $\begin{array}{l}\text { Soakin } \\
\mathrm{g} \\
\text { washin } \\
\mathrm{g}\end{array}$ & $\begin{array}{l}\text { Washin } \\
\mathrm{g}\end{array}$ & $\begin{array}{l}\text { Soakin } \\
\mathrm{g} \\
\text { washin } \\
\mathrm{g}\end{array}$ \\
\hline Rice & 1.29 & 1.26 & 9.93 & 3.56 & 0.13 & 0.14 & 3.68 & 2.90 \\
\hline Split red gram & 2.37 & 2.27 & 5.29 & 4.92 & 0.25 & 0.28 & 10.86 & 9.69 \\
\hline $\begin{array}{l}\text { Split black } \\
\text { gram }\end{array}$ & 1.74 & 1.62 & 20.32 & 14.78 & 0.12 & 0.12 & 2.36 & 3.69 \\
\hline $\begin{array}{l}\text { Split green } \\
\text { gram }\end{array}$ & 1.00 & 1.09 & 3.91 & 3.16 & 0.11 & 0.13 & 10.68 & 9.50 \\
\hline $\begin{array}{l}\text { Split bengal } \\
\text { gram }\end{array}$ & 0.96 & 1.33 & 5.26 & 4.86 & 0.12 & 0.13 & 10.72 & 6.08 \\
\hline $\begin{array}{l}\text { Whole green } \\
\text { gram }\end{array}$ & 2.16 & 2.04 & 5.22 & 4.93 & 0.22 & 0.25 & 14.85 & 5.69 \\
\hline Kidney beans & 2.09 & 1.84 & 4.44 & 2.00 & 0.14 & 0.13 & 8.60 & 18.00 \\
\hline Potato & 0.9 & 0.84 & 1.63 & 1.54 & 0.11 & 0.11 & 2.32 & 3.73 \\
\hline Tomato & 1.12 & 1.06 & 1.98 & 2.01 & 0.13 & 0.09 & 5.02 & 8.09 \\
\hline Spinach & 1.29 & 1.20 & 7.77 & 8.42 & 0.12 & 0.12 & 3.29 & 8.68 \\
\hline $\begin{array}{l}\text { Fenugreek } \\
\text { leaves }\end{array}$ & 2.15 & 1.33 & 1.97 & 8.58 & 0.27 & 0.26 & 9.39 & 9.90 \\
\hline Cabbage & 2.09 & 2.08 & 1.81 & 1.80 & 0.25 & 0.26 & 4.03 & 2.90 \\
\hline Cauliflower & 1.32 & 0.85 & 7.52 & 6.44 & 0.26 & 0.13 & 3.23 & 3.15 \\
\hline Egg plant & 2.11 & 2.06 & 1.97 & 2.07 & 0.12 & 0.10 & 4.00 & 9.05 \\
\hline Guava & 0.63 & 1.19 & 5.83 & 1.97 & 0.25 & 0.23 & 4.68 & 2.77 \\
\hline Sapota & 2.06 & 2.04 & 1.86 & 1.97 & 0.08 & 0.14 & 3.30 & 4.05 \\
\hline
\end{tabular}

Table $3.2 \mathrm{~b}$ Effect of pre treatments on the metal content of raw organic foods $(\mu \mathrm{g} / \mathrm{g})$

\begin{tabular}{|c|c|c|c|c|c|c|c|c|}
\hline Food & \multicolumn{2}{|l|}{$\mathrm{Cr}$} & \multicolumn{2}{|l|}{ Al } & \multicolumn{2}{|l|}{ Cd } & \multicolumn{2}{|l|}{$\mathrm{Cu}$} \\
\hline & Washing & $\begin{array}{l}\text { Soaking } \\
\text { washing }\end{array}$ & Washing & $\begin{array}{l}\text { Soaking } \\
\text { washing }\end{array}$ & Washing & $\begin{array}{l}\text { Soaking } \\
\text { washing }\end{array}$ & Washing & $\begin{array}{l}\text { Soaking } \\
\text { washing }\end{array}$ \\
\hline Rice & 1.43 & 1.49 & 0.08 & 1.45 & 0.80 & 0.79 & 0.39 & 0.44 \\
\hline $\begin{array}{ll}\begin{array}{l}\text { Split } \\
\text { gram }\end{array} & \text { red } \\
\end{array}$ & 1.48 & 1.48 & 1.41 & 1.24 & 0.42 & 0.51 & 1.17 & 0.98 \\
\hline $\begin{array}{l}\text { Split } \\
\text { gram }\end{array}$ & 1.56 & 1.45 & 6.59 & 3.75 & 0.75 & 0.47 & 0.95 & 0.61 \\
\hline $\begin{array}{ll}\begin{array}{l}\text { Split } \\
\text { gram }\end{array} & \text { green } \\
\end{array}$ & 2.02 & 1.69 & 0.50 & 0.46 & 0.75 & 0.47 & 1.11 & 1.78 \\
\hline $\begin{array}{l}\text { Split bengal } \\
\text { gram }\end{array}$ & 1.66 & 1.49 & 1.51 & 6.54 & 0.51 & 0.80 & 3.29 & 0.92 \\
\hline $\begin{array}{l}\text { Whole green } \\
\text { gram }\end{array}$ & 1.83 & 1.26 & 1.10 & 0.14 & 0.39 & 0.46 & 1.76 & 1.60 \\
\hline Kidney beans & 1.55 & 1.08 & 0.45 & 1.46 & 0.82 & 0.18 & 1.09 & 0.71 \\
\hline Potato & 1.48 & 1.33 & 2.77 & 0.65 & 0.68 & 0.46 & 0.37 & 0.30 \\
\hline Tomato & 1.41 & 1.36 & 1.62 & 18.71 & 0.75 & 0.73 & 0.36 & 0.41 \\
\hline Spinach & 1.58 & 1.73 & 0.74 & 2.64 & 0.79 & 0.75 & 0.42 & 0.39 \\
\hline $\begin{array}{l}\text { Fenugreek } \\
\text { leaves }\end{array}$ & 1.58 & 1.60 & 0.72 & 10.87 & 0.48 & 0.76 & 0.34 & 0.45 \\
\hline Cabbage & 1.68 & 1.55 & 0.30 & 0.13 & 0.50 & 0.75 & 0.69 & 0.30 \\
\hline Cauliflower & 1.44 & 1.00 & 0.97 & 6.04 & 0.67 & 0.19 & 0.31 & 0.22 \\
\hline Egg plant & 1.38 & 1.54 & 0.35 & 0.18 & 0.56 & 0.71 & 0.31 & 0.22 \\
\hline Guava & 1.50 & 1.21 & 0.28 & 1.04 & 0.66 & 0.59 & 0.78 & 0.57 \\
\hline Sapota & 1.47 & 1.74 & 0.42 & 0.35 & 0.41 & 0.61 & 0.47 & 0.34 \\
\hline
\end{tabular}




\subsection{Metal content of cooked organic foods}

The organic foods were cooked in the laboratory by standard household procedures and the change in metal content after cooking is given in Table 3.3.

Table 3.3 Mean Metal content of cooked organic foods $(\mu \mathrm{g} / \mathrm{g})$

\begin{tabular}{|l|l|l|l|l|l|l|l|l|l|}
\hline Foodstuff & $\begin{array}{l}\text { Average daily } \\
\text { intake (g) }\end{array}$ & $\mathbf{A l}$ & $\mathbf{C d}$ & $\mathbf{N i}$ & $\mathbf{P b}$ & $\mathbf{C r}$ & $\mathbf{Z n}$ & $\mathbf{F e}$ & $\mathbf{C u}$ \\
\hline Cereals & 203 & 9.14 & 0.62 & 1.4 & 0.12 & 1.27 & 3.07 & 7.12 & 0.46 \\
\hline Pulses & 56 & 0.49 & 0.54 & 2.07 & 0.25 & 1.54 & 3.13 & 8.92 & 0.53 \\
\hline Whole legumes & 11 & 0.18 & 0.62 & 2.15 & 0.26 & 1.57 & 3.08 & 5.04 & 0.68 \\
\hline Roots and tubers & 53 & 0.53 & 0.31 & 1.76 & 0.19 & 1.34 & 1.72 & 7.34 & 0.31 \\
\hline Vegetables & 94 & 0.85 & 0.37 & 1.99 & 0.12 & 1.34 & 2.19 & 3.93 & 0.47 \\
\hline Leafy vegetables & 36 & 2.45 & 0.56 & 1.53 & 0.24 & 1.59 & 2.22 & 7.64 & 0.35 \\
\hline
\end{tabular}

The analyzed cooked organic foods showed highest content of $\mathrm{Al}$, followed by $\mathrm{Fe}, \mathrm{Zn}, \mathrm{Ni}, \mathrm{Cr}, \mathrm{Cd}$, and $\mathrm{Cu}$. Al was found to be highest in cereals $(9.14 \mu \mathrm{g} / \mathrm{g})$ followed by leafy vegetables $(2.45 \mu \mathrm{g} / \mathrm{g})$. Fe content was found to be highest in pulses $(8.92 \mu \mathrm{g} / \mathrm{g})$ followed by leafy vegetables $(7.64)$, roots and tubers $(7.34 \mu \mathrm{g} / \mathrm{g})$, cereals $(7.12 \mu \mathrm{g} / \mathrm{g})$, whole legumes $(5.04 \mu \mathrm{g} / \mathrm{g})$ and other vegetables $(3.93 \mu \mathrm{g} / \mathrm{g})$. Zn content was found to be highest in pulses (3.13) followed by whole legumes, cereals, leafy vegetables, other vegetables, roots and tubers. $\mathrm{Cr}$ levels were found to be highest in leafy vegetables $(1.59 \mu \mathrm{g} / \mathrm{g})$. Highest values for $\mathrm{Ni}$ were found in whole legumes $(2.15 \mu \mathrm{g} / \mathrm{g})$ followed by pulses $(2.07 \mu \mathrm{g} / \mathrm{g})$. A study done on conventionally grown foods reported $\mathrm{Ni}$ values to be $0.63 \mu \mathrm{g} / \mathrm{g}$ in cereals which are much lower than the values reported in the present study. Al content was reported to be in the range of $4.85-3.72 \mu \mathrm{g} / \mathrm{g}$ in the cooked vegetables which is higher than the values reported in the present study. [10].

Health risk assessment was done using various indices such as PTDI, PTWI, PTMI, PMTDI, TDI, UL for all the metals and it was found that health risk was associated with $\mathrm{Cd}$ and $\mathrm{Ni}$ as they exceeded the safe intake limits given by various agencies. All the other metals were well within the safe intake limits.

The PTDI values calculated for Cd were compared with the PTDI cutoffs given by JECFA [23]. The calculated PTDI values from organic foods were much higher $(3.28 \mu \mathrm{g} / \mathrm{kg})$ than the PTDI cutoffs $(1 \mu \mathrm{g} / \mathrm{kg})$. The values calculated were almost 3 times higher than the cutoffs. A study done in Vadodara on conventionally grown cooked foods recorded the PTDI for $\mathrm{Cd}$ as $0.73 \mu \mathrm{g} / \mathrm{kg}$ which was lower than the PTDI cutoffs. [10] . The PTWI values calculated for Cd in the present study were much higher $(22.96 \mu \mathrm{g} / \mathrm{kg})$ than the PTWI cutoffs $(2.5 \mu \mathrm{g} / \mathrm{kg})$. A study done in Vadodara on conventionally grown cooked foods reported Cd levels to be 1.6 times higher than the PTWI cutoffs. [10]. The PTWI values for Ni reported in the present study exceeded the PTWI cutoffs of $35 \mu \mathrm{g} / \mathrm{kg}$. The Ni levels reported were $53.41 \mu \mathrm{g} / \mathrm{kg} /$ week which is 1.53 times higher than the PTWI cutoffs. A study done in Vadodara on conventionally grown cooked foods reported the PTWI values 2.14 times higher than the PTWI cutoffs, which is almost similar to the results obtained in the present study [10]. The PTMI values for $\mathrm{Cd}$ are much higher $(98.4 \mu \mathrm{g} / \mathrm{kg})$ than the PTMI cutoff $(25 \mu \mathrm{g} / \mathrm{kg})$. The values are almost 3 times higher than the PTMI cutoffs. The TDI values for Ni obtained were higher $(7.63 \mu \mathrm{g} / \mathrm{kg} / \mathrm{d})$ than the TDI cutoffs $(5 \mu \mathrm{g} / \mathrm{kg} / \mathrm{d})$. The TDI values calculated were 1.53 times higher than the TDI cutoffs. A study done in Vadodara on conventionally grown cooked foods reported TDI values which were almost double the TDI cut off of $10.89 \mu \mathrm{g} / \mathrm{kg} / \mathrm{d}$. [10].

\section{Conclusion-}

The results from present study indicate that the organic foods analyzed had lower content of all the metals except Cadmium as compared to the values reported by various researchers on both conventionally and organically grown raw foods. Further investigations on effect of various pre treatments and cooking methods should be undertaken to arrive at best processing methods to reduce metal load in foods and the associated health risk. Health risk was associated with consumption of Cadmium and Nickel from organic foods.

\section{References-}

[1]. Jarup L (2003). Hazards of heavy metal contamination. British Medical Bulletin 68: 167-182

[2]. Lopes C., Herva M., Uría A. F. \& Roca E. (2011). Inventory of heavy metal content in organic waste applied as fertilizer in agriculture: evaluating the risk of transfer into the food chain, Environ Sci Pollut Res, 18, 918-939

[3]. Haritash A. K. and Kaushik C. P. (2007). Assessment of Seasonal Enrichment of Heavy Metals in Respirable Suspended Particulate Matter of a Sub-Urban Indian City, Environ Monit Assess, 128, 411-420

[4]. Bhagure G. R. and Mirgane S. R. (2011). Heavy metal concentrations in groundwater and soils of Thane Region of Maharashtra, India. Environ Monit Assess, 173:643-652

[5]. Krishna A. K. and Govil P.K. (2004). Heavy metal contamination of soil around Pali Industrial Area, Rajasthan, India. Environmental Geology, 47, 38-44.

[6]. Ling-yu B., Xi-bai Z. , Lian-fang L, Chang P. and Shu-hui L. (2010).Effects of Land Use on Heavy Metal Accumulation in Soils and Sources Analysis, Agricultural Sciences in China, 9 (11), 1650-1658 
[7]. Qishlaqi A. \& Moore F. \& Forghani G. (2008). Impact of untreated wastewater irrigation on soils and crops in Shiraz suburban area, SW Iran. Environ Monit Assess, 141, 257-273.

[8]. Narayanan S. (2005). Organic farming in India: Relevance, problems and constraints, Occasional paper 38, dept of economic analysis and research, National Bank for agriculture and rural development, Mumbai.

[9]. Dotse C. K. (2010). Assessing Commercial Organic and Conventionally Grown Vegetables by Monitoring Selected Heavy Metals Found in Them. East Tennessee University, MI, The United States.

[10]. Bajaj P. and Chandorkar S. (2012). Health risk assessment due to metal contamination of food-a total diet study. Unpublished thesis of the department of foods and nutrition, The M. S. University of Baroda, Vadodara, India.

[11]. Uchino T, Roychowdhury T., Ando M, Tokunaga H. (2006). Intake of arsenic from water, food composites and excretion through urine, hair from a studied population in West Bengal, India, Food and Chemical Toxicology, 44, 455-461

[12]. Roychowdhury T., Tokunaga H, Ando M. (2003). Survey of arsenic and other heavy metals in food composites and drinking water and estimation of dietary intake by the villagers from an arsenic-affected area of West Bengal, India. The Science of the Total Environment, 308, 15-35

[13]. UK total diet study http://archive.food.gov.uk/maff/archive/food/infsheet/1999/no191/table5.htm accessed on 23/03/2013

[14]. Raghuramulu N., Nair K. M., \& Kalyanasundaram (Eds.). (2003). A Manual of Laboratory Techniques (2 ed.). Hyderabad: National Institute of Nutrition.

[15]. JECFA. 2001.Summary and Conclusions-56th Meeting of the Joint FAO/WHO Expert Committee on Food Additives. Geneva: World Health Organization.

[16]. Deota P. and Chandorkar S. (2011). Heavy metal content of foods and health risk assessment in the study population of Vadodara. Unpublished thesis of the department of foods and nutrition, The M. S. University of Baroda, Vadodara, India.

[17]. Ramesh H. L. and Murthy V. N. Y. (2012). Assessment of Heavy Metal Contamination in Green Leafy Vegetables Grown in Bangalore Urban District of Karnataka. Advances in Life Science and Technology, 6, 40-51.

[18]. Jafarian A. and Alehashem M. (2012). Heavy metal contamination of vegetables in Isfahan, Iran. Research in Pharmaceutical Sciences; 8(1), 51-58.

[19]. Orisakwe O. E., Nduka J. K., Amadi C. N., Dike O. D. and Bede O. (2012). Heavy metals health risk assessment for population via consumption of food crops and fruits in Owerri, South Eastern, Nigeria., Chemistry Central Journal, 6:77, 1-7.

[20]. Habib M. N., Sultana S., Gomes R. And Noor S. (2012). Heavy Metal Pollution of Soil and Vegetable Grown Near Roadside at Gazipur, Bangladesh J. Agril. Res. 37(1): 9-17.

[21]. Soliman K. M. (1999). Changes in concentration of pesticide residues in potatoes during washing and home preparation. Food and chemical toxicology, 39:887-891.

[22]. Arab A. A. K. (2001). Heavy metal contents in Egyptial meat and the role of detergent washing on their levels. Food and chemical toxicology, 39, 593-599.

[23]. JECFA (2003). Summary and conclusions of the sixty-first meeting of the Joint FAO/WHO Expert Committee on Food Additives (JECFA). JECFA/61/SC. 